\title{
From Rolling Thunder to Reggae: \\ Imagining Squatter Settlements in \\ Papua New Guinea
}

\section{Michael Goddard}

E

arly in the morning of 4 February 1998 police raided the old, abandoned parliament building in downtown Port Moresby, Papua New Guinea. Adjacent to the central business district, where high-rise buildings had mushroomed during the decade, the dilapidated building had in recent years been the subject of calls for preservation as a national monument. Its exterior was crumbling and overgrown with weeds, its interior long since looted of anything indicative of its former dignity. It had become the habitat of squatters, whose presence had provoked complaints from the downtown business community for some time. Now, suddenly, they were evicted, in an operation the police had code-named "Enough Is Enough," though it was never made clear who gave the order. Senior staff at the National Museum, who had been prominent advocates of the building's preservation, denied rumors that they were behind the eviction $(P C, 4,5$ Feb I998).

A few days previously the police had raided the Baruni dump, a rubbish tip on the "back road" that connected Port Moresby's northwest suburbs to the downtown area circuitously through a relatively uninhabited stretch of land to the coast west of the city. The "back road" (officially known as Baruni Road; map I) has long had a reputation for armed holdups and the perpetrators in recent times were popularly said to come from the ranks of the squatters at the dump, who scoured their habitat constantly for materials to build shelters, sell at the roadside, or turn to other subsistence purposes. The police found some stolen vehicles hidden behind the dump, and while the raid on the dump community itself disclosed no stolen property, the stolen vehicles were used as justification for the eviction of the dump squatters and the torching of their makeshift shelters in

The Contemporary Pacific, Volume I3, Number I, Spring 200I, I-32

(C) 200 I by University of Hawai'i Press 


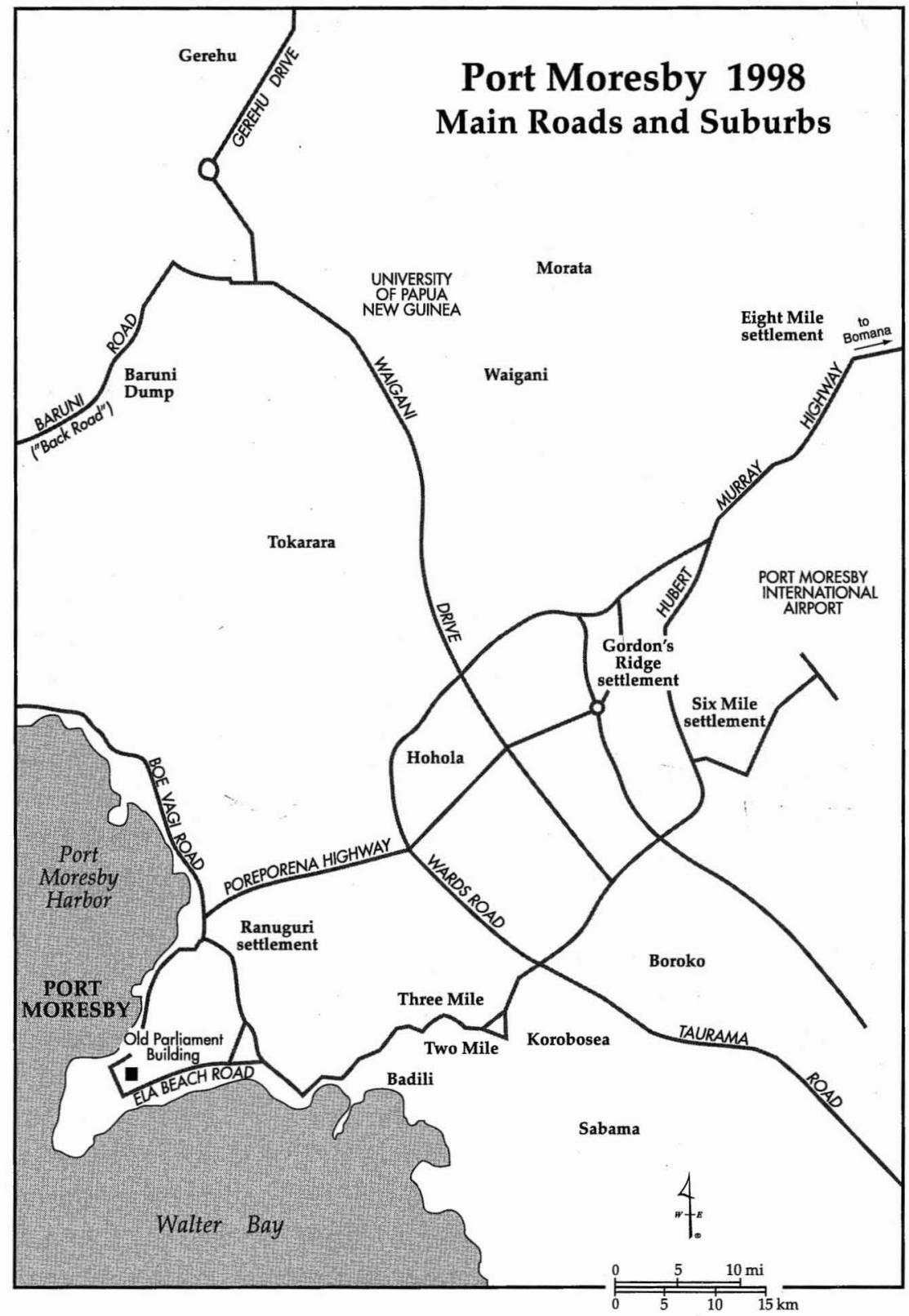

MAP I. Main roads and sites mentioned in text. 
the planned operation the police had code-named "Rolling Thunder" (PC, 30 Jan, 6 Feb I998).

Both raids were conducted in the climate of calls for a solution to the problem of "squatters" and "settlements" in general, and debate over proposals for the reintroduction of a Vagrancy Act similar to that which had existed during the colonial period (National, I3, I9 Feb I998; PC, I6, I9 Feb I998). The "settlement" issue has waxed and waned several times in the past two decades in an ongoing debate on what to do about unemployment and crime, which are causally linked in popular discourse. In the mid I990s its intensity seemed to have heightened, and for the first time was reflected in a noticeable rise in practical action against urban settlements and squatters by police and provincial authorities around the country. Local authorities ordered mass evictions of selected settlements in Rabaul and Lae late in I994, for example, and while police were evicting the Baruni-dump and old-parliament-building squatters the Madang Provincial Government was preparing to bulldoze a large and long-established settlement whose existence was hampering the development of business premises in the provincial capital.

Evictions such as these have been a common occurrence in third-world towns and cities since mass urban migration and the connected phenomena of squatters and shantytowns became an issue, and state responses on several continents have moved more or less cyclically through attempts to discourage migrants to attempts to upgrade existing settlements and plan self-help or low-cost housing areas (see, eg, Drakakis-Smith I98I, I 13-I67; I990, 99-I09; Dwyer 1979; Gilbert 1986; Gilbert and Gugler 1987, 97-107). As uncontrolled settlements continue to appear and grow, responses have sometimes included intimidation to the point of violence (see, eg, Scheper-Hughes 1992). Common popular perceptions of squatter settlements and shantytowns link themes of uncontrolled migration, unemployment, extreme poverty, and crime, characterizing settlement populations as maladjusted and undesirable in urban society. The attitudes reflected in the responses of the Papua New Guinean state, through police, the media, and local authorities, resonate with those observed, for instance, in Asia (Dwyer 1979, 45) and Latin America (Drakakis-Smith I98I, 83-84; Scheper-Hughes I992). The comment by Nancy ScheperHughes, writing of a Brazilian shantytown, that impoverished rural migrants are "seen as a kind of modern-day plague, an unruly cancerous growth, an infectious epidemic inflicted on the once healthy and sound 
social body of the community" could be extended to third-world cities in general, as could her perception of "a hegemonic discourse on criminality/deviance/marginality and on the 'appropriateness' of police and state violence in which all segments of the population participate and to which they acquiesce, often contrary to their own class or race interests" (Scheper-Hughes I992, 94, 225).

Yet some paradoxes emerged during and after the Baruni-dump and old-parliament-building evictions, suggesting that stereotypic models of the squatter phenomenon and state responses cannot be visited on Papua New Guinea without qualification. After being evicted with great fanfare by armed police and ferried to a nearby police station, the parliamentbuilding squatters were within a few hours allowed to drift back to the vicinity of the building. As they milled in the street the prime minister of the time, Bill Skate, arrived and distributed food and drinks, promising to look into their plight (National, 4 Feb I998). The following day they were offered payment to assist museum staff clean the building $(P C, 5$, Io Feb 1998). No such pleasantries were offered the Baruni-dump squatters, but by midyear they had moved back onto the dump, and the Salvation Army was publicizing its weekly visits to them to distribute food and drinks ( $P C$, I 5 July 1998). No move was made to re-evict them. Later in the year a video clip accompanying "Born to Suffer," a reggae song about poverty and hunger in resource-rich Papua New Guinea by a local band called Bad Mix Souls, showed the squatters scavenging at the dump.

There is little doubt that the increased demands for action on "settlements" had been fueled by the concerns of the business community about the detrimental effects of crime and images of urban squalor on economic development and attempts to attract overseas interest and investment. The Port Moresby Chamber of Commerce publicly applauded the old-parliament-building eviction and commented that local businesses "could now look forward to some respite from unruly elements" ( $P C, 5$ Feb 1998). Arguably, though, the discursive linking of settlements, unemployment, and crime, a theme popular with politicians, police spokespeople, and the business community and monotonously repeated in the daily press, is in need of critique. The popular notion that settlements are criminogenic, by virtue of a population said to be largely unemployed and pauperized, is reinforced by the frequency of police raids, some of which are well-publicized in the local press as components of "crackdowns" on crime (usually with well-broadcast operation "code names") and contextualized in a rhetoric about inevitable consequences of urban migration and poverty. Inventories of stolen goods found and people arrested (if at all) in the 
police raids are usually vague, however, compared to the accounts of the raids themselves.

Events in the aftermath of the Baruni-dump raid cast some equivocality on civil authorities' vilification of squatters and urban settlers. In the weeks following the eviction of the dump squatters, intermittent armed holdups continued to occur on the back road (eg, PC, 3 March I998). After a police stakeout a gang was finally caught (PC, 26 April I998). It had been using the area behind the dump as a gathering point and hiding-place for stolen vehicles, members then dispersing to their homes in other suburbs. It can be assumed that the dump squatters knew about the gang's operations but had been intimidated or bribed into silence. The use of particular settlements as operational gathering and dispersal points is common among urban gangs, exploiting the criminal imagery of settlements to misdirect the immediate vengeance of their pursuers and victims. The origin and resilience of this generalized imagery of settlements is the main subject of the discussion that follows, which situates it in the particular context of late colonialism in Papua New Guinea and subsequent urban developments when the country gained political independence. While the growth of settlements and responses of authorities in Papua New Guinea share some commonalities with other third-world countries there are also important differences, and a consideration of these may contribute to an understanding of the paradoxes manifest in the conciliatory gestures to the old-parliament-building squatters by the prime minister and museum staff and the permitted return of the Baruni-dump squatters. Concentrating mostly on Port Moresby, the capital city, I begin with a review of the development of urban housing from immediately after the Second World War, when significant urban migration began, through Papua New Guinea's transition in the mid I970s from a colony to an independent nation. This will contextualize the development of the derogatory imagery of "squatter settlements" in European discourse in the late colonial era, and I subsequently discuss the perpetuation of this imagery to the present time and its relationship to episodes like "Rolling Thunder" and "Enough Is Enough."

\section{Housing After the Second World War}

With the easing of restrictions on the movement of indigenes into urban areas in the aftermath of the Second World War, migrants began to trickle steadily into Port Moresby. The colonial administration had no general long-term program for housing the newcomers, in what had become in 
many respects an Australian small town (Oram I976a, 4I). Before the war, indigenous workers recruited from beyond the immediate villages had been accommodated in barrack and dormitory conditions. In that period the only habitats in Port Moresby not fully controlled by European interests were the local villages of the Motu people, the traditional coastal inhabitants of the area who had intermarried to a degree with the Koita who lived inland. A few of the early postwar migrants from other areas managed to establish themselves in these villages, on the basis of old trading relationships and sometimes through intermarriage with the MotuKoita. Apart from this, migrant housing in the decade following the war was principally of three types: workers' "compounds" established by government departments and companies such as the traders Burns Philp, Carpenters, and Steamships; domestic quarters attached to European residences (commonly referred to by Europeans in kitchen pidgin as "boy houses"); and so-called settlements.

The establishment of the first postwar settlements was achieved not by illicit squatting but by arrangement with local traditional landowners, as in the well-documented case of Rabia Camp at Kaugere (Hitchcock and Oram 1967), and occasionally with town authorities (eg, Norwood I984). The distinction between these two types of liaison was less clear in practice than on paper, since the Motu-Koita regarded the Port Moresby urban area as essentially their land, despite some areas having been acquired by the administration through early transactions that it classified as purchase. For example, a downtown settlement, Ranuguri, which is partly on government land and partly on customary land, began when migrants from the Gulf District were invited to move into buildings vacated by the army at the end of the war. According to some commentators (eg, Rew I974, 6; Ryan I970, I9) the arrangement was intended as a temporary measure by the administration while it built proper housing for employees. Although this suggests that the administration itself told the settlers to move into the buildings, there is equivocation among the settlers over who issued the invitation. For instance, I was told by a long-term settler that his kin had been invited by the customary landowners to take over the buildings. This interpretation, which ignores official classification of the piece of ground on which the buildings stood as government land, is predicated on the old trading relationships between Motu and Gulf people, and on the established Motu practice of inviting individuals from their trading-partner groups to settle on their land.

The settlements grew in size and number as the firstcomers were joined 
by near and distant kin from their places of origin. Their growth caused concern both to traditional landholders (Ryan I968, 6I) and to the administration. For the Motu-Koita landholders it became increasingly difficult to collect the rent-in-kind or continue the personal exchange relationships that had been integral to the negotiations with the first small groups of settlers (Levine and Levine 1979, I8). The administration feared the prospect of overcrowding and the gradual transformation of small but tidy groups of makeshift houses into large and unruly conglomerates. When the settlements first appeared they were tolerated by the administration because they provided a solution to the problem of housing workers during postwar reconstruction. But after a few years officials became fearful that a migrant underclass would develop. Some settlements were at one point denied water supplies and garbage and sanitary services in an attempt to discourage the migrants, according to Ryan $(1993,222)$, or to remove the settlers from land required for other purposes, according to Oram (I976a, I96). Other strategies, such as plans by a Housing Commission (established in I968) to resettle the occupants in better organized cheap housing estates, came only to partial fruition (Oram I976a, I9Iff).

By the I970s the administration had accepted the inevitable presence of settlements (Oram I976a, I85-205; Stuart I970, 288-290) and had moved from attempts to discourage them to various assistance schemes, a transition that mirrored similar changes in government policies elsewhere in the third world (see, eg, Dwyer 1979, 78-I I7, I88-227; Drakakis-Smith I990, 99-I09; Gilbert I986). In 1973 the flow of people into town was beyond the capacity of the Housing Commission's resettlement scheme, and new self-help policies were introduced (Bryant 1977; Rabuni and Norwood I980). Some existing settlements were provided with paved footpaths and basic services like water taps, and blocks of land were allocated on selected sites around the town on which people could build their own shelter (theoretically in accordance with building regulations). The scheme was elaborated to include financial loans to enable tenants to build adequate housing for themselves. One product of the combination of the Housing Commission's resettlement plan and the self-help policies was the development of Morata suburb on the edge of the Port Moresby town area, a planned operation that began in I97I and involved both rental and self-help housing (Bryant 1977). In addition community welfare groups attempted to assist particular settlement populations in their efforts to get basic services such as water supplies and to develop handcrafts and other income-generating activities (see, eg, Mylius I97I). 
In retrospect, the attempts by the colonial administration to deal with the continual arrival of migrants through the development of a variety of habitats in the late colonial period, documented by Oram (I976a, I67208 ), can be seen as a process of piecemeal reaction, rather than systematic planning. As Oram has pointed out, the distribution of housing areas in Port Moresby by the end of the colonial period did not conform to any recognizable spatial theory (I976a, I00). There were "high-covenant" housing areas almost exclusively occupied by Europeans, low-covenant planned estates such as the "partially integrated" (Stuart I970, 307) suburb of Hohola with a few Europeans but mostly housing Papua New Guineans, cheaper rental housing, self-help ("no-covenant") housing areas, the original settlements, company compounds, and domestic quarters. While some cheap indigenous housing areas established by the administration were deliberately sited away from high-covenant European residential areas (Oram I976a, IOI) they were not hidden, but lined major roads and were not far distant from European housing, while some workers' compounds and all domestic quarters were integrated into Europeandominated areas.

The difference between high-covenant housing for Europeans and lowcovenant and other types of housing for Papua New Guineans in the late colonial era is conventionally related in literature to other racially segregatory practices of the period (eg, Hastings 1973, 99ff; Kiki 1966, 72; Ward I970, 60; Wolfers I975, I 19, I 54ff). But, importantly, the variety of indigenous urban housing itself engendered another type of distinction. There was a perceptual dichotomization by Europeans of migrant Papua New Guinean urban habitats, based on a concatenation of the spatial relationship between European and indigenous housing and the degree of orderliness of the latter. The low-covenant houses, company compounds, and domestic quarters were reasonably tidy in appearance, and their comparative physical proximity to European housing implied the relative social proximity of their inhabitants, as workmates, subordinates, or domestic servants. This was not necessarily manifest in friendly relations; discriminatory attitudes and cultural misunderstanding were common (Nelson 1972, I68-I72; Wolfers I975, I 52ff) and regular occupational contact and interaction did not guarantee friendly socializing outside working hours. But the image of social proximity, however limited, was in contrast with that engendered for Europeans by the migrant settlements on customary and government land and the self-help housing areas, a little more removed from the elite European housing estates and rarely 
entered by whites. The initial small settlements that appeared in the immediate postwar period had been neatly laid out (Oram I976a, I85), but took on an increasingly untidy appearance as they grew. Similarly, in the self-help housing areas an unruly impression was created by the improvised nature of houses, made from whatever material settlers could obtain, and the asymmetrical clusters on land blocks originally planned by surveyors. A social researcher of the period, who bemoaned the "appalling symmetry" of the rows of neat low-covenant houses and preferred the creative approach of self-help housing areas, conceded that "To European eyes the results may not be as aesthetically pleasing as are the serried ranks of little boxes" (Ward I970, 60; cf, Levine and Levine I979, 4).

Literature on third-world settlements, and slums in general, commonly makes the point that such habitats are unfairly judged by outsiders on their untidy appearance (eg, Drakakis-Smith I98I, 88ff; Gilbert and Gugler I987, I28). The aesthetic judgment of settlements in urban Papua New Guinea was not made in a simple comparison with European housing styles or architecture, however, but was contextualized in a dualism of European style and an idealized "traditional" rural village. In this respect settlements and architecturally changing urban villages were both seen as aesthetically deviant. In a discussion of the growth of Lae, a city at the mouth of the Bumbu River on Papua New Guinea's northeastern coast, Willis commented on the five "traditional" villages immediately across the river mouth:

Despite their proximity to the city they have not yet been assimilated into it and are still a separate entity. The village houses, often built from reclaimed scraps of timber, iron and fibro-cement, seem dilapidated even by comparison with the houses in the adjacent "squatter" camps. They stand in strong contrast to the neat bungalows of the city and to the other traditional villages to east and west where houses are still built of native materials and have a neat, post-card picturesqueness. (Willis I974, I45; italics mine)

Under the labels "settlements" or "squatter settlements" or sometimes "shantytowns" (a term that has now almost disappeared) the customary and government land settlements and the no-covenant housing areas were discursively collapsed together, reinforcing the image of a socially distant population. The connection of a spatial and aesthetic dichotomy of urban indigenous habitats with a relative degree of social distance of their inhabitants from the economically dominant white population was reflected in journalistic literature of the period. For example Peter Hast- 
ings wrote in 1969 of an "urban proletariat, unskilled, living on the breadline in shanties erected in increasing numbers on the bare brown hills of that disagreeable town. ... a polyglot force of men without jobs, women or land-the dispossessed of the new dispensation" (I973, 90). Osmar White in 1972 similarly sequestered in print those migrants to Port Moresby who "set up squalid shantytowns on its perimeters, subsisting as best they could on wages for casual, unskilled labour" (I972, 200-20I). ${ }^{1}$

Sociological research did not support this image. Richard Jackson commented that while there might be a "grain of truth" in the view of settlements as repositories of ill-adjusted transients, "a strong case can be made in support of the opposite view: that the settlements are frequently the homes of people less transitory, no more unemployed and just as urbanized as other sectors of the population" $(1976,49)$. A survey in another town, Popondetta, had shown that nearly two-thirds of the administration's laborers and many tradesmen lived in settlements (Jackson 1976, 49), as did "business managers, teachers, and two members of the national Parliament" (Jackson 1977, 32). An examination of the Six Mile settlement in Port Moresby in the I970s indicated that about 70 percent of the adults were employed (Levine and Levine 1979, 37) and in a sample of settlements in several urban centers it was found that households (largely built around nuclear families) contained an average of between one and two wage earners (Jackson 1977, 32; Levine and Levine 1979, 42). In this respect Papua New Guinea's settlement dwellers were socioeconomically similar to those in many other third-world settlement and slum communities (see Drakakis-Smith I990, 94-99; Dwyer 1979, 45-49; Gilbert and Gugler 1987, 88-89; Roberts 1982, 376). Yet the image of dispossessed squatters in settlements, contrasting with a more socially proximate working urban indigenous population in other types of housing, prevailed in popular European discourse. Although this simple dichotomy misrepresented the complex demography of Port Moresby, ${ }^{2}$ it became institutionalized discursively, and has survived the colonial period and an ongoing process of change in the nature and variety of habitats in Port Moresby.

In the r960s some settlers who could more justifiably be called squatters were appearing in Port Moresby. The earlier settlements were enclaves of people sharing a region of origin, such as the Eastern Gulf people at Ranuguri settlement, or Purari people at Rabia camp. Later migrants from other areas, particularly the highlands, were naturally excluded from building houses in these existing micro-ethnic enclaves. Lacking traditional exchange links with Motu-Koita landholders, or the wherewithal to 
obtain no-covenant land blocks from the administration, those who were unable to negotiate some kind of arrangement with customary landholders were often obliged to find a niche on unused government land. An example is Gordons Ridge settlement where migrants from the Simbu and Goilala districts developed discrete groups of shelters on a hill overlooking one of the most exclusive European housing estates. Their appearance caused concern among the Europeans below, and many of the migrants were persuaded to resettle at Morata, the newly developed suburb containing a mixture of low-covenant and no-covenant housing. However, some squatters remained, and the Gordons Ridge settlement gradually developed, with the inhabitants improving their dwellings, planting trees, and building an access road (Norwood I984, 34). Their habitat was consolidated and gained legitimacy, if not absolute legality, as it grew in the I980s.

By the I970s a broad range of housing, from unauthorized buildings on government land, through various types of customary or administration-authorized dwellings on unused land, to planned self-help housing on leased blocks, was being referred to in common European discourse as "the settlements" or "squatter settlements." The broad and indiscriminate use of such terms, together with the difficulty of precisely categorizing the variety of indigenous housing that had developed in Port Moresby, may have been responsible for the disparity in academic literature of the period (among empirically careful researchers) in representations of the numbers of "settlements" in existence at different points in time from the I950s until the I970s. ${ }^{3}$ In the face of ongoing changes in the nature of the town's habitats, the institutionalized notion of settlements (incorporating the notion of squatters), proved resilient in the following years.

\section{HOUSING AFTER INDEPENDENCE}

When Papua New Guinea became an independent nation in 1975, and the European population began to dwindle, the housing areas it had inhabited were taken over by indigenes. This substitution, in combination with ongoing housing projects, increasing urban migration, and the demands of the extended kin systems typical of Melanesian societies, began to change the spatial distinction between the housing types discussed earlier, without significantly altering the institutionalized notion of a dichotomy of "settlements" and formal (ie, low- and high-covenant) housing. Building 
projects were extending some of the formal housing estates in the outer suburbs to the point where they began to connect with self-help housing areas, which had originally been discrete, and with enclaves of squatters who had established themselves quietly at the periphery of the urban area since the I960s. At the same time the inhabitants of these peripheral areas were building extensions to, or upgrading, their houses if they were able. Consequently, while some settlements remained demarcated by boundary fencing, the overall visual and spatial distinction between squatter settlements, legitimate settlements, and planned low-cost housing estates became less clear in some outer suburbs. In addition, the untidy development of suburbs with basic infrastructure provided the opportunity for individuals or families to establish illicit dwellings in the interstices of growing communities of migrants from a variety of ethnic backgrounds, where few questions of legitimacy were asked unless serious trouble arose. In this respect, for example, parts of the formerly European-dominated suburb of Boroko and of the low-covenant suburb of Hohola now have a mixture of housing types significantly different from what existed in the early i970s.

A further change after independence was that the homologic relationship between two- or three-bedroomed housing and European nuclear families was displaced under Melanesian kinship sensibilities. The exigencies of an unavoidable obligation to provide assistance to members of one's extended kingroup-referred to with ambivalent sentiments as the "wantok system" by urban Papua New Guineans (wantok is a Tokpisin term used to refer to kin, both near and distant) - meant that the urban house became a locus of the nominal occupants' kindred. It has been argued by Keith Barber that it is analytically useful to regard urban Papua New Guinean households not as physical units of co-residence but more flexibly as sets of changing social relations, acknowledging the social context in which they are embedded (I993, 26-27). This perspective avoids positing households as fixed sets of people, and more accurately reflects the change in the nature of householding when European residents were replaced by indigenes. Household numbers fluctuated with the movement of relatives both from home areas into town and back, and among wantoks' residences in town. This did not escalate into major overcrowding of individual houses however, ${ }^{4}$ although domestic quarters attached to highcovenant houses were now often used as accommodation for migrant kin.

An associated phenomenon was a new kind of squatter, the "illegal" occupant of formal housing. As industry grew in Papua New Guinea's 
towns, large-scale employers rented houses, or blocks of houses, for employees. "Compounds" now included all types of housing, up to relatively luxurious dwellings for the new Papua New Guinean elite as well as for highly paid foreigners. Where colonial employers had enforced the expulsion and exclusion of illicit occupants of compound and rental housing (mostly the wantoks of employees) relatively efficiently, Melanesian sensibilities made the task far more difficult for indigenous bosses, even though the policy of evicting such occupants remained. For example, when I lived in the large housing compound of the University of Papua New Guinea in the early I990s, constant complaints were made by legitimate inhabitants and those employees waiting to be allocated housing about the number of squatters occupying dwellings of various kinds. These were often relatives of employees who had gained access to houses through their kinship connections, and sometimes were ex-employees of the university who had simply failed to move out. Despite the occasional flurry of memoranda and threats of forcible eviction, there was little real action against them. Administrative staff (including some who were complainants) were constrained as a body by the dense kinship networks under which the squatters had established themselves in the first place.

Developments such as these indicated an ongoing housing problem in the capital city, which was a legacy of the colonial administration's slow response to postwar urban migration, an absence of adequate long-term town-planning, and a lack of affordable housing for non-elite workers. By the late I980s a new belt of self-help settlements, on leased land blocks, was beginning to establish itself at a few kilometers' remove from the expanding city's edge in an area where there had previously been only one or two small settlements containing single micro-ethnic groups (see, eg, Vele 1978). As well as serving recent migrants from rural areas, these habitats were the recourse of former city dwellers seeking refuge from the financial problems of living in town and the increasing limitations on personal freedoms presented by Port Moresby's growth. Moving to locations such as Eight Mile ${ }^{5}$ was a strategy to avoid the city's "law-and-order" problems, obtain access to gardening land, yet remain close enough to take advantage of employment opportunities in town (Barber 1998).

In contemporary Port Moresby, although most settlements established during the late colonial period still exist, and illicit housing is still built by squatters, the distinction between different types of urban habitat and the associated socioeconomic status of inhabitants is even less clear than it was by the early I970s. Squatters can be found in many types of hous- 
ing, from high-covenant to illicit lean-to shelters, and while some self-help areas have boundary fencing, there is no clear spatial separation overall between various types of urban "settlements" and other types of housing. Despite the increasing complexity in the mixture of housing in the contemporary city, the discursive dichotomization of its habitats into legitimate housing and "settlements" has survived from colonial times. I now turn to this dichotomy, and the attendant imagery that links migrants, unemployment, and crime to a particular type of urban habitat, and examine its resilience in the face of empirical change.

\section{The Resilient Imagery of Settlements}

The generalized European imagery of settlements in the late colonial period was of a spatially separate and disorderly collection of habitats implying the social distance of the people who occupied them, as I have shown. The dichotomizing imagery itself was engendered by the dominant ideology of the colonizers that posited Melanesian societies as essentially rural, traditional, and primitive in contrast to urbanizing, modern, and civilized western societies. In European-dominated urban settings the orderliness of habitats - that is, the degree to which they fitted with the overall physical appearance of a range of housing modeled on that of a subtropical Australian small town-served as one putative measure of the degree of civilization attained by indigenes. The rural-urban dualism itself was also a taken-for-granted component of the body of modernization theories that informed western approaches to decolonization in the r96os and I970s, whereby an earlier resource extraction program and "civilizing" mission were recast as a "development" program. In the era of decolonization, development programs were aimed at enabling what was presumed to be an inevitable but problematic evolutionary transition from the "traditional" to the "modern" that could be theorized in terms of the sociological, psychological, and economic progress of the general population (Larrain I989, 87-98). As Jorge Larrain has pointed out $(1989,87)$, terminological substitutions like "rural" and "backward," or "urban" and "developed" can be made in respect of the two ideal society types posited in the modernization model, the "traditional" and the "modern."

In Papua New Guinea the colonial administration had carefully controlled the movement from rural "traditional" society to urban "modern" society before the Second World War. After the war, modernization was 
expected to involve a long and difficult process of broad education. In a I950 policy statement, Australian Minister for External Territories P C Spender said of the prospect of the "advancement" of Papua New Guineans, "This will take a very long time but the natives have shown that with the proper guidance and given the opportunity they have the capacity to carry out both manual and mental tasks in accordance with our concepts" (Spender, cited in Jinks, Biskup, and Nelson I973, 340-34I). The traditional image of Melanesians, and its problematic nature for the modernization programs of Europeans, was implicit in diplomatic references to "native" customs, such as Spender's assurance (in the same policy statement) that in education and technical training activities "care is taken to preserve the structure of native tribal life and native customs that are not harmful or repugnant to humanity." It was more explicit in assessments like that of Assistant Administrator J T Gunther in I958: "Their houses are crudely built and uncomfortable; they have next to no furniture of the kind that gives us some comfort in our living, their cooking methods are crude, their eating utensils practically nil. Compared with ours, their farming methods are almost non-existent" ( 1958,57$)$. In commonsense European perceptions, the urban environment was the appropriate habitat of the modernizing, rather than the traditional, Papua New Guinean: "It is the cities, not the villages, which are the centres of civilization, culture, commerce, industry and education in any country. It is in them that new ideas are encountered, new knowledge acquired, new skills learned, new relationships established and new wealth exchanged. A country without cities is doomed to stagnation and backwardness" (Stuart I970, 289).

In the light of the view that the "advancement" of the majority of Papua New Guineans, seen as traditional villagers, was going to involve a long process of training, uncontrollable urban migration following the Second World War signaled a pathological situation for the colonizers-the premature arrival of the primitive into the modern environment. The concept of the "squatter settlement," the disjunctive urban habitat, neatly encapsulated this impetuous engagement of the ill-prepared primitive with civilization. Whatever reason was attributed by observers to the migration of villagers - the attraction of the bright lights, the need for a cash income, the avoidance of village social responsibilities, the drudgery of traditional life or its breakdown (cf, Levine and Levine I979, 28-32; Clunies Ross I984, 5-10)-the consequences were assumed to be the same. The migrants arrived in town without funds, jobs, modern work skills, or proper accommodation. Institutionalized in a homogenizing 
colonial discourse, the terms settlements and squatter settlements (used interchangeably) had come by the mid I970s to imply habitats peopled by unemployed migrants living in poverty and various degrees of squalor, socially distant from more legitimate urban dwellers, and inclined to criminal activity. Used in this way the terms demonstrate some of the qualities Victor Turner attributed to emotionally forceful symbols: a number of meanings ("poverty," "unemployment," "crime," etc) are condensed into a single symbolic form ("settlements"), and the term permits therefore an "economy of reference" (Turner I972, 29).

However, the meanings condensed into the term settlements derived not so much from the immediate urban reality of the later colonial period as from the collective popular imagination of Europeans. For instance, the imagery of journalists such as Hastings (1973) and White (1972) did not accord with the sociological findings of Jackson (I976) and others on the socioeconomic status of settlement dwellers overall. The imagined criminogenic nature of settlements (linked to the assumption that settlement dwellers were mostly unemployed) was no better supported by empirical investigation. Social researchers in the late colonial era reported that criminal gangs of the era included both employed and unemployed people (Po'o I975; Utulurea I98I), and that economic deprivation was not a key factor (Young 1976). As late as 1983, an officially commissioned review of crime, law, and order, drawing on recent research findings, stated that "on the face of it institutional housing compounds, urban villages and migrant settlements have low arrest rates," that "formally subdivided suburbs have high arrest rates," that "it has never been shown that migrants in urban settlements are more criminally inclined than the rest of the comunity," and that "low crime rates are known to exist in certain urban ethnic groups, or settlements" (DPA I983, I6I-I63). Yet the ideology of inevitable pathology in urbanization-unemployed migrants living in squalid housing turning to crime-was impervious to empirical research. An urban geographer lamented "The 'squatters' are caricatured as unemployed and lawless, and their settlements as disease-ridden communities of ill-adapted drifters, unnecessary blots on the national escutcheon" (Jackson I977, 27).

Indigenous urban dwellers of the late colonial period had different prejudices. There was resentment at the general segregation, including housing policies, practiced by Europeans. A prominent indigenous political figure, Albert Maori Kiki, expressed this polemically: "We are put in settlements such as Hohola and Kaugere, away from white people. Our 
settlements are places for the white man's sexual outlet" (I966, 72). Hohola was actually a low-covenant housing area; Kiki conflated lowcovenant and settlement housing in his statement. His use of the term settlements was thus not a simple reproduction of European popular usage but, importantly, an appropriation to an indigenous viewpoint connoting socially segregated, rather than informal, housing, a point I return to later. There were also issues of resentment between indigenous groups. In Port Moresby, Motu-Koita concerns at the growth of settlements after the Second World War were subsumed under their general concern at the growth of the colonial town on their traditional land. ${ }^{6}$ As most of the earlier postwar settlers had been Papuan and historically familiar by virtue of old trading relations, potential hostility toward their increasing numbers was displaced by a shared antagonism toward a newer problem. Growing numbers of migrants were arriving from the highlands and coastal New Guine $\mathrm{a}^{7}$ and were seen as socially distant competitors for housing, jobs, and services. Papuans stereotyped "New Guineans" negatively, portraying Highlanders in particular as violent and primitive and regarding themselves as peaceful and civilized in contrast (cf, Chatterton I975, 284; McKillop 1982, 334). In turn the Highlanders stereotyped Papuans as lazy, and regarded themselves as enterprising and industrious. Papuan stereotyping of "New Guineans" (generally a synecdoche for Highlanders) extended to seeing them as land-grabbers and their settlements as less legitimate than those of Papuan migrants. In the I970s the distinction between settlements inhabited by "Papuans" and those inhabited by "New Guineans" developed political significance, particularly in the campaigns of the Papuan separatist movement, Papua Besena, headed by Josephine Abaijah, the first indigenous woman in parliament. Realizing the importance of campaigning in settlements as well as in villages (Abaijah I991, I88-I94; Premdas and Steeves I983, 54), Abaijah exploited the regional stereotypes to advantage, particularly in the 1977 elections, and an analysis of results showed overwhelming support for her in the Papuandominated settlements (Premdas and Steeves I983, 40, 55, 59).

Regional distinctions continue to be an issue in urban Papua New Guinea, and tensions manifest themselves in occasional violent confrontations. In formal housing estates micro-ethnic enclaves rarely develop, as individual migrant families move into houses, or are assigned them by employers, where and when they become available around the towns. In contrast, self-help areas and other informal habitats are typified either by single micro-ethnic populations, such as those from the Gulf region in the 
older settlements in Port Moresby, or by groups from several regions who arrange themselves territorially on the land available for building. The second type of group is found mostly in those self-help areas established since the I960s, and mutual distrust can result in simmering tension and the possibility of hostilities. At the end of the colonial era, occasional noisy confrontations in some self-help communities, and the resulting police intervention, fueled popular European views of settlements as sites of trouble, even though the altercations rarely spread beyond the immediate habitats in which they occurred, and were-and still are-exacerbated rather by friction over shared space and resources than by extreme poverty, squalor, or criminal proclivities. Among the self-help settlements themselves, those dominated by Papuans are to the present day quick to differentiate between their own allegedly peaceful habitats and those they regard as giving settlements a bad reputation (Goddard 1998) - and which they stereotype, often inaccurately, as Highlander-dominated.

The incorporation of settlements into regional antagonisms in the late colonial era meant that among Papua New Guineans they were classified according to the regional identities of their inhabitants instead of being negatively distinguished from other indigenous habitats. In addition, the prevalence of the wantok system in the indigenization of Port Moresby and other urban centers from the late r970s meant that kinship ties transcended different types of habitat. People living in high-covenant housing estates usually had kin living in settlements, and visits between relatives consolidated the social proximity of the variety of urban habitats. Conceivably, these developments contained the potential to effect a replacement of the European concept of "squatter settlements" with an alternative classification of urban habitats reflecting the indigenous social reality of wantokism and ethnic and regional divisions. Yet the popular colonial imagery of squatter settlements survived and in the r990s continued to pervade journalistic portraits of the independent nation. For example, in a popular book on contemporary Papua New Guinea a veteran journalist gives an account of several pages that juxtaposes urban crime, poverty, and "settlements" (Dorney I993, 299-309). The suburb of Morata is referred to, inaccurately, as "one of the largest and longest established" squatter settlements in Port Moresby (I993, 303). The author expresses no judgmental view, and the discussion acknowledges that "squatter settlements" are victimized by police and that settlers resent being labeled thieves (I993, 302). Despite Dorney's neutrality, however, the account's reliance on an influential sociological paper on criminal gangs (Harris 
I988) and anecdotal evidence from a former police chief about raids on settlements $(1993,303)$ results in their being discursively positioned as criminogenic habitats.

Far from disappearing with the end of European political domination, the negative condensation of migration, poverty, and crime in the image of settlements had by the r99os become conventionalized to the point where it was also being taken for granted in some academic literature. For example, the substance of contemporary introductory courses on Papua New Guinea history at the University of Papua New Guinea was reproduced in a 1993 publication (by a prominent Papua New Guinean academic) which deployed the ideation of "settlements" with efficient brevity under the subheading "Law and Order": "As village society broke down more and more, villagers moved to the urban areas in the hope of employment and greater access to Western goods. As there was no housing for most of these people, they built shanties out of any available materials and created squatter settlements. As there was very often no employment for them, many turned to crime" (Waiko I993, 217).

Importantly, the perpetuation of the imagery of squatter settlements into the r980s involved a polemical addition to the meanings it contained, based on a popular Papua New Guinean dichotomization (in PNG English) of the country's population into grassroots and elites. ${ }^{8}$ This development was prefigured by the previously mentioned resentment at segregation enforced by a European elite, articulated for example by Kiki in his remarks about Papua New Guineans being consigned to "settlements" (1966, 72). Stereotyping indigenous elites as rich, greedy, self-serving, and appropriating the economic standing and housing of departing Europeans, rural and urban grassroots positioned themselves discursively as the underclass, the unrewarded backbone of the country. In towns the term settlements symbolized their putative living conditions and frustrations, but also served hyperbolically to symbolize the habitat of the "real" people of urban Papua New Guinea. ${ }^{9}$ Given the overall socioeconomic complexity of contemporary Papua New Guinea, including the high proportion of self-defined "unemployed" who are actually engaged in informal economic activities that often produce more income than conventional wage work (Barber 1993; Levantis 1997), the elites-grassroots dichotomy is as reductive and misleading as the popular colonial dichotomy that preceded it (see M Turner 1990, 68-76). However, the potential of the obverse, positive meaning added to those already existing in the simplistic imagery of settlements appropriated from European usage cannot be overlooked. 
Recent Prime Minister Bill Skate used it to advantage in the 1997 elections, campaigning in the city as a "man of the people," visiting settlement communities, and achieving an unprecedented urban legitimacy partly by emphasizing his upbringing in a "squatter settlement" in Port Moresby and his understanding of grassroots issues. ${ }^{10}$ The elites-grassroots dichotomy is also employed in the practiced rhetoric of so-called raskols (Tokpisin: "rascals," street crime gangs) who like to promote themselves to researchers as avengers of the poor against those in power (Morauta I986, I I; Goddard I992, 30; I995, 58; Levantis I997), and who are usually portrayed in the media as settlement dwellers.

Arguably, the multivocality of the imagery of "squatter settlements" contributes significantly to its resilience in contemporary times. In popular discourse it can "speak" of unemployment, poverty, crime, but also of urban integrity and social injustice. Consequently, the generalized concept of "settlements" can be brought into discursive play in different and sometimes contrary contexts. In one, benignly, it connotes dispossession as an inevitable burden of urbanization and economic rapacity, a discursive theme of liberal commentators and welfare agencies urging charitable attitudes toward a generalized category of penurious settlers (eg, Chao I989). The publicity given the Salvation Army's feeding program (PC, I 5 July 1998) at the Baruni dump belongs to this discourse, as does the video clip accompanying Bad Mix Souls' song "Born to Suffer." The song was written to express the socioeconomic conditions the band members said they shared with many other Papua New Guineans. Yet its production had to negotiate some discongruity between the realities of informal housing and the homogenizing notion of squatter settlements and attendant poverty. The band members were residents of self-help settlements on Port Moresby's periphery ( $P C, 24$ Nov 1998). The most pressing problems for these settlements, like most others around the city since settlements began to develop half a century ago, are not mass unemployment but the lack of services like piped water, proper access roads, and sanitation. In order to effectively illustrate the song's theme of disparities between the rich and the poor (born of the elites-grassroots dichotomy), the group used an image not from their own settlements but from the well-publicized Baruni dump, one of the few habitats in Port Moresby, out of all those referred to as "squatter settlements," that empirically fits the imagery of a truly penurious urban community. An overlapping discursive context in which the concept of squatter settlements is employed is that of the integrity of grassroots, the downtrodden toilers of the new nation. The former prime 
minister's self-legitimating references to his settlement upbringing belong in this context, and his urban reputation as an advocate of grassroots is maintained by acts like his arrival to give handouts and verbal comfort to the squatters evicted from the old parliament building.

The most powerful discourse, however, since it legitimates the occasional destruction of "squatter settlements" ranging from dump scavengers to self-help housing areas, is that which collapses together unemployment, poverty, and crime. However, in contemporary Papua New Guinea, popular media images and politicians' rhetoric of criminal-infested settlements are no more supported by careful research than they were in earlier decades. The National Vice-President of the Papua New Guinea Social Workers Association commented in 1994, "Port Moresby residents are well aware that criminals operate from suburban areas like Hohola, Gerehu or Boroko ... which are certainly not settlements" (Wrondimi I994, 4). He added, "Mass eviction is definitely not a solution to resolve criminal activities in urban centres; since such activities are also perpetrated . . . by white collar workers who hold high positions and live in high covenant, tight-security residences. . . . Recent discussions with settlers in Rabaul and Lae indicate that the majority of them, in fear of losing their temporary residence on the land, are not involved in criminal activities" (Wrondimi 1994, I 8).

Research in Port Moresby in the early I990s also indicated that members of so-called raskol gangs came from a variety of socioeconomic backgrounds and could not be generalized as the products only of squatter settlements (Goddard I992, I995). Moreover, its findings did not support the generalization that unemployment "causes" crime. Interviews with gang members in I99I revealed that many found crime more lucrative than waged work, and had either left formal employment for crime or supplemented their legitimate income with it. Some, enticed into raskolism at school age, had never seriously considered formal employment. Overall, the interview material suggested that the conditioning relationship between unemployment and raskolism may well be the reverse of what is popularly thought (Goddard I992, 2I). Questionnaire research by Levantis in I995 appears to support my findings, with self-defined raskols, of whom a high proportion were not seeking formal wage work, indicating that crime pays better than (at least) average wage work (Levantis I997).

Successive governments in independent Papua New Guinea have been dogged by the publicity given to the country's crime problem, and to urban crime in particular. A series of commissioned reports, reaching its zenith 
in the massive "Clifford Report" (Clifford, Morauta, and Stuart 1984), has revealed the overwhelming complexity of the issue and produced no simple solutions. As Dinnen stated, "The impression is one of escalating lawlessness, on the one hand, and a progressively ineffectual crime control system, on the other" (I992, I). The measures mooted have included states of emergency and curfews (both of which have been implemented for short periods) as well as vagrancy laws, identity cards, and more draconian punishment of offenders. Nothing has provided a satisfactory solution, and politically expedient state responses to crime have "increasingly entailed bypassing the normal processes of criminal justice in favour of more visible and direct exercises of state power" (Dinnen I992, 3). Given that criminological applications of global theories of modernization or dependency assume crime-and especially "street" crime-to be a product of urbanization and rapid social change (Dinnen I992, I7-I8; Goddard I995, 56-57), it is not surprising that public displays of crime control are directed at those constituencies most easily portrayed as the defaulters in the urbanization process. Unemployed, undereducated migrants are blamed for crime, and the imagery of squatter settlements is brought into play as politicians and police seek a social site that collectivizes such people for the purposes of displays of crime-fighting efficiency.

Although "squatter settlements" provide a handy focus for political rhetoric and dramatic images of efficient crime fighting (press reporters were present at the parliament-house and Baruni-dump evictions and are given police publicity statements after some planned raids on settlements), the alternative discursive contexts of "settlements" weaken the potential of a sustained campaign against informal housing. Both the Rolling Thunder and Enough is Enough raids were publicized as the beginning of a sustained program of settlement evictions (as the image of rolling thunder suggests) that did not eventuate. Most residents of Port Moresby, including the elites, are migrants or, in the case of a younger generation, the children of migrants. And most, if they do not live in informal housing, have wantoks who do. Given the currency of the elites-grassroots imagery, the crosscutting social ties, and the discontinuity between the realities of informal housing and the homogenizing notion of "settlements" it is possible for people to vacillate between benign and censorious settlement imagery. A surge in street crime or a threat to business interests from international media focusing on the nation's law-and-order problems can trigger censorious polemic against squatter settlements. Conversely, corruption in high places and chronic rough handling of ordinary people by the police trig- 
gers the rhetoric that grassroots are dispossessed and unfairly consigned to life in settlements. Eviction programs cannot be sustained for any length of time in the face of such ambiguity. On a wave of frustration and anger in some sections of the general urban community early in I998, two small and vulnerable communities of squatters, unable to legitimate their presence through any appeal to customary or other land-use arrangements, were easily routed. But Rolling Thunder was a fanciful metaphor. A continued program of evictions and destruction of "settlements" would mean engagement with a much wider range of informal housing, with a significant proportion and socioeconomic range of the urban population, and with the tortuous wantok networks linking the poor to the rich and the powerless to the powerful, threatening the ideological notion of "squatter settlements."

Police raids on settlements and the occasional destruction of individual settlements can be legitimated by appeals to the negative imagery of squatter settlements, but in some cases the mobilizing of alternative imagery can create the paradoxes evident in the case of the old-parliament-building and Baruni-dump evictions. Thus the police satisfy the business elites and demonstrate their efficient response to the law-and-order problem by dramatically evicting the parliament-building squatters, and a prime minister satisfies the grassroots and demonstrates his populism by commiserating and giving them food handouts. The Baruni-dump squatters can be used at one moment to demonstrate police commitment to crime control, at another to publicize social welfare initiatives, and at yet another to illustrate a pop song about the division between rich and poor. The alternative imagery is equally bound, of course, to a homogenizing notion of "squatter settlements" and would be as vulnerable as the criminal imagery to exposure as falsification if practical interventionist responses were extended beyond a handful of genuinely penurious habitats.

\section{Conclusion}

While the negative portrayal of urban settlement communities in Papua New Guinea has much in common with a stereotype found in third-world countries elsewhere, it cannot be explained simply by generalizing without qualification from existing critiques of the hegemonic discourses used to legitimate mistreatment of migrants in informal housing (eg, Dwyer I979; Drakakis-Smith I98I; Scheper-Hughes I992). The discursive representation of settlements in Papua New Guinea must be understood in the 
context of its own unique history. To this end I have traced the homogenizing imagery of "squatter settlements" in Papua New Guinea, from its origins in the imagination of late colonial Europeans, through its appropriation by Papua New Guineans after independence, to its prevalence in contemporary times.

This imagery did not in the late colonial period, and does not now, accurately reflect the real diversity of urban housing, especially informal housing. The imagery, which has gained additional meanings in indigenous usage, is employed in different discursive situations to connote dispossession, unemployment, and in its most censorious use, criminalitythe last being a practical threat to those who live in informal housing, as it is used to justify police raids and sometimes eviction. As researchers have occasionally pointed out, "settlements" ("informal housing" is a better, though still imperfect, descriptive term) are essentially a response to inadequate housing policies since the end of the Second World War and provide habitats for a wide socioeconomic range of people, as indeed do settlements and slums in other parts of the world. An investigation in 1994 in a Lae "squatter settlement," for instance, revealed that about threequarters of the population was in some kind of employment (Kaitilla I994, 646). Further, social research since the I970s has not shown informal housing to be a greater breeding ground for criminals than other types of housing (I am not, of course, suggesting that there are no criminals living in informal housing). The categorical demonizing of settlements, partly sustained by the frequency of well-publicized police raids rather than by their findings, is certainly undeserved.

Settlements are vulnerable not only to police raids but also to the criminals they are alleged to harbor. There used to be a notable contrast between the fortress-like appearance of postindependence formal housing, encased in high fencing and barbed or razor wire, and the absence of fortification in settlements. But in recent years high-security fencing has begun to appear in some self-help settlements as householders attempt to protect themselves against Port Moresby's endemic burglaries and armed attacks. During a vacation visit in 1998 I commented humorously to friends in a self-help settlement that some of their neighbors' houses looked as well fortified as those of the elites. The conversation quickly became serious, as people discussed the "law-and-order" problem, the rascal gangs, and the police raids. Romantic portraits were painted of an idyllic life "at home" in villages as now-familiar complaints were reiterated about the deteriorating quality of life in the city. "I am tired of the raskols, I am tired of 
the police, I am tired of trying to sleep with the sound of gunshots. I am afraid for my children," said Rani, a community worker, "I am trying to persuade my husband to move to Eight Mile [ie, to one of the new selfhelp settlements outside the city]. If not, I want to take the children and go back to our ples [home village, place of origin]."

There is no easy solution to crime in Papua New Guinea, and there is certainly no clearly definable criminal constituency for the state to engage with. Wrondimi's $(\mathbf{1 9 9 4}, 4)$ comment that Port Moresby's residents are well aware that criminals operate from suburban areas other than settlements (with which, as a former resident, I concur) raises the question of whether the censorious diatribes about settlements, the frequent police raids, and the sporadic evictions of the most vulnerable of squatters serve a wider purpose than a show of governmental and police competence in the struggle to achieve law and order. Given the systemic and insoluble presence of crime throughout urban society, and the frustration of the public as a whole, it is tempting to perceive settlements as scapegoats in the strict sense of that term, in that an innocent party is ritually designated the bearer of the sins of the community as a whole and consigned to an extra-civic fate. Sadly, in the absence of improvements in urban housing programs, and with no indication of a significant abatement of raskolism in the short term, good citizens in informal housing are likely to continue to be the victims of the cyclopean responses of urban authorities.

THIS PAPER IS PARTLY INFORMED by acquaintance, over a number of years, with various people living in informal housing in Port Moresby. Their individual stories are not told here, and they should remain anonymous, but I was partly motivated to write this piece by concern for the uncertainties with which they are obliged to live. I am indebted to them for whatever understanding I may have of their situation. I benefited from discussions with Barry Morris and Keith Barber at an early stage in this paper's production, and from comments by anonymous reviewers. The interpretations and conclusions are my own.

\section{Notes}

I It is questionable whether the images used in these journalistic portraits are based on detailed local observation. They are commonly found in characterizations of "typical" third-world shantytowns (see, eg, Dwyer 1979, 45; Yeung and Belisle 1986, I00). 
2 An ethnography by Alan Rew, who did participant observation fieldwork in a company compound in Port Moresby in the I960s, and a discussion by Richard and Mary Salisbury, also based on participant observation during the I960s, give a good indication of the complex relationship between employment and habitat during this period (Rew 1974, Salisbury and Salisbury 1972).

3 For example Oram, drawing on his own findings and those of government reports, listed in one publication the number of settlements as I4 in I950, I8 in 1964, and 40 in 1970 (Oram 1976b, I 52). Two maps in the same article showed 25 and 3 I settlements respectively (I976b, I 54, I67). A loose map with the same volume showed 3I settlements, but not all in the same locations as on the second map in Oram's article. An article by Jackson in the same volume gave the number of settlements in 1976 as "over 40" (Jackson 1976, 63). Oram repeated his statistics (with the first date as 1956 instead of 1950) in his book on Port Moresby, in which a map showed only 27 settlements in 1974 (I976a, 99, I76). Groves, Hamilton, and McArthur (I97I, 28I) cited a list compiled by the "Sub-District Office" identifying 22 "squatter shanty settlements" in about I964. A map in Rew (1974, I4) showed only I9 settlements in 1969 (the time of his fieldwork).

4 A household survey by King in 1987 across all housing types, while arguably committing the conceptual error Barber avoided, found an "average" household of seven (husband, wife, three children, two other relatives), against the popular belief that indigenous urban households were inundated with wantoks (King I992, 6). It should be acknowledged, of course, that "overcrowding" is a term in need of qualification in respect of differing cultural conceptions of the relationship between numbers of people and adequate domestic resources.

5 The name refers to the distance from downtown Port Moresby. Since the colonial period, locations along the Hubert Murray Highway from downtown Port Moresby to the airport and beyond have been referred to locally by this method. Thus Two Mile, Three Mile, Four Mile, and so on are alternatives to more conventional names found on formal maps, and in several cases are more familiar to city residents. It remains to be seen whether the new Poreporena Highway linking the downtown area to Gordons by a shorter route has an effect on these informal mapping idioms.

6 Similar concerns were felt on the other side of the country by landholders in Lae. See Adams (1982) for an account of local responses to perceived land loss and settlement growth.

7 New Guinea refers to the northern half of the nation, a residual distinction from the colonial era. While the highlands topographically straddled the colonial dividing line between Papua and New Guinea, coastal and lowland Papuans tend to classify all Highlanders as New Guineans.

8 In PNG English the plural elites refers to members of a putative socioeconomic group that Europeans would call (collectively) "the elite." PNG English thus allows for the singular case, whereby an individual can be referred to as "an elite." Similarly there is a class of grassroots and an individual can be referred to 
as a "grassroot." These terms have also been taken into (urban, mostly) Tokpi$\sin$.

9 In the I980s a cartoon character called Grass Roots, developed by the PostCourier newspaper's cartoonist Bob Browne, enjoyed enormous popularity. Grass Roots was a trickster whose income came from dubious activities like black marketeering. It was not made clear exactly where he lived, but the popular inference was a Port Moresby settlement, probably Six Mile.

Io Bill Skate grew up in Sabama settlement, which was first established in the I95 Os on customary land adjacent to, and owned by, the Koita urban village of Kila Kila, near the suburb of Badili in Port Moresby (Norwood 1984, 49).

\section{References}

Abaijah, Josephine

I99I A Thousand Coloured Dreams. Mt Waverly: Dellasta Pacific. Adams, $\mathrm{R}$

I982 City and Village: The Ahi Response. In Micronationalist Movements in Papua New Guinea, edited by R J May, 207-245. Political and Social Change Monograph I. Canberra: Research School of Pacific Studies, Australian National University.

Barber, Keith

1993 The Informal Sector and Household Reproduction in Papua New Guinea. Discussion Paper 7I. Port Moresby: National Research Institute.

I998 Contemporary Indigenous Urban Households in Papua New Guinea. Manuscript, University of Waikato.

Bryant, Jenny J

I977 Urbanization in Papua New Guinea: Problems of Access to Housing and Services. Pacific Viewpoint I 8 (I): 43-57.

Chao, Sister M John Paul

I989 A New Sense of Community: Perspectives from a Squatter Settlement. In The Ethics of Development: In Search of Justice, edited by Charmian Thirlwall and Philip J Hughes, 88-I06. Port Moresby: University of Papua New Guinea Press.

Chatterton, Percy

I975 Perspectives on Papua Besena. Meanjin 34 (3): 280-285.

Clifford, W, Louise Morauta, and B Stuart

I984 Law and Order in Papua New Guinea, volumes I and 2. Port Moresby: Institute of National Affairs and Institute of Applied Social and Economic Research.

Clunies Ross, Anthony

I984 Migrants from Fifty Villages. Monograph 2I. Port Moresby: Institute of Applied Social and Economic Research. 
Dinnen, Sinclair

I992 Crime, Development and Criminological Research in Papua New Guinea. Discussion Paper 66. Port Moresby: National Research Institute.

Dorney, Sean

I993 Papua New Guinea. Sydney: Random House.

DPA, Department of Provincial Affairs, Papua New Guinea

I983 Report of Committee to Review Policy and Administration on Crime, Law and Order. Port Moresby: Government Printer.

Drakakis-Smith, David

I98 I Urbanisation, Housing and the Development Process. London: Croom Helm.

I990 The Third World City. London: Routledge.

Dwyer, D J

I979 People and Housing in Third World Cities: Perspectives on the Problem of Spontaneous Settlements. New York: Longman.

Gilbert, Alan

I986 Self-Help Housing and State Intervention: Illustrative Reflections on the Petty Commodity Production Debate. In Urbanisation in the Developing World, edited by David Drakakis-Smith, I75-I94. New Hampshire: Croom Helm.

Gilbert, Alan, and Josef Gugler

I987 Cities, Poverty, and Development: Urbanization in the Third World. Oxford: Oxford University Press.

Goddard, Michael

I992 Big-man, Thief: The Social Organization of Gangs in Port Moresby. Canberra Anthropology I 5 (I): 20-34.

I995 The Rascal Road: Crime, Prestige, and Development in Papua New Guinea. The Contemporary Pacific 7:55-80.

I998 Off the Record: Village Court Praxis and the Politics of Settlement Life in Port Moresby, Papua New Guinea. Canberra Anthropology 2I (I): 4I-62.

Groves, Murray, R M S Hamilton, and Margaret McArthur

I97 I A Town and Its Hinterland. In The Politics of Dependence: Papua New Guinea I968, edited by A L Epstein, R S Parker, and Marie Reay, 275-3I4. Canberra: Australian National University Press.

Gunther, J T

I95 8 The People. In New Guinea and Australia, edited by J Wilkes, 46-66. Sydney: Angus \& Robertson.

Harris, Bruce

I988 The Rise of Rascalism: Action and Reaction in the Evolution of Rascal Gangs. Discussion Paper 54. Port Moresby: Institute of Applied Social and Economic Research. 
Hastings, Peter

I973 New Guinea: Problems and Prospects. Melbourne: Cheshire.

Hitchcock, N, and Nigel D Oram

I967 Rabia Camp: A Port Moresby Migrant Settlement. New Guinea Research Bulletin I4. Canberra: Australian National University.

Jackson, Richard T

I976 A Social Geography of Urban Papua New Guinea. In An Introduction to the Urban Geography of Papua New Guinea, edited by Richard T Jackson, 28-70. Dept of Geography Occasional Paper I3. Port Moresby: University of Papua New Guinea.

I977 The Growth, Nature and Future Prospects of Informal Settlements in Papua New Guinea. Pacific Viewpoint I 8 (I): 22-42.

Jinks, B, P Biskup, and Hank Nelson, editors

I973 Readings in New Guinea History. Brisbane: Angus \& Robertson.

Kaitilla, Sababu

I994 Urban Residence and Housing Improvement in a Lae Squatter Settlement, Papua New Guinea. Environment and Behavior 26 (5): 640-668.

Kiki, Albert Maori

I966 Go Home (Some) Australians! New Guinea and Australia, the Pacific and South-East Asia I (6): 7 I-73.

King, David

I992 Socio-economic Differences Between Residential Categories in Port Moresby: Results of a University of Papua New Guinea Urban Household Sample Survey of Port Moresby, I987. Yagl-Ambu I6 (3): I-I6.

Larrain, Jorge

I989 Theories of Development. Cambridge, ma: Polity Press.

Levantis, Theodore

I997 Urban Unemployment in Papua New Guinea: It's Criminal. Pacific Economic Bulletin I 2 (2): 73-84.

Levine, Hal, and Marlene Levine

I979 Urbanization in Papua New Guinea: A Study of Ambivalent Townsmen. Cambridge: Cambridge University Press.

McKillop, Bob

I982 Papua Besena and Papuan Separatism. In Micronationalist Movements in Papua New Guinea, edited by R J May, 329-358. Political and Social Change Monograph I. Canberra: Research School of Pacific Studies, Australian National University.

Morauta, Louise

I986 Law and Order: A Tenth Anniversary Report. In Law and Order in a Changing Society, edited by Lousie Morauta, 7-I9. Canberra: Australian National University. 
Mylius, Beth

I97 I Report of the Port Moresby Community Development Group. Journal of the Papua and New Guinea Society 5 (2): Io8-I I4.

The National. Daily. Port Moresby.

Nelson, Hank

I972 Papua New Guinea: Black Unity or Black Chaos? Middlesex: Penguin. Norwood, Hugh

I984 Port Moresby Urban Villages and Squatter Areas. Port Moresby: University of Papua New Guinea Press.

Oram, Nigel D

I976a Colonial Town to Melanesian City. Canberra: Australian National University Press.

I976b Port Moresby. In An Introduction to the Urban Geography of Papua New Guinea, edited by Richard T Jackson, I40-I72. Department of Geography Occasional Paper I3. Port Moresby: University of Papua New Guinea.

Po'o, Tau

I975 Gangs in Port Moresby. Administration for Development 3:30-37.

PC, Post-Courier. Daily. Port Moresby.

Premdas, Ralph, and Jeffrey S Steeves

I983 Secessionists versus Central Authority: Papua Besena in the Elections. In Electoral Politics in Papua New Guinea: Studies on the 1977 National Elections, edited by David Hegarty, 38-60. Port Moresby: University of Papua New Guinea Press.

Rabuni, Tang, and Hugh Norwood

I980 Informal Settlement Planning in PNG. In Urbanisation and Its Problems in Papua New Guinea: Papers Presented to the 1979 Waigani Seminar, edited by Richard Jackson, John Odongo, and Patrick Bath, 326-340. Port Moresby: University of Papua New Guinea Press.

Rew, Alan

I974 Social Images and Process in Urban New Guinea: A Study of Port Moresby. New York: West Publishing.

Roberts, Bryan

I982 Cities in Developing Societies. In Introduction to the Sociology of “Developing Societies,” edited by Hamza Alavi and Teodor Shanin, 366-386. New York: Monthly Review Press.

Ryan, Dawn

I968 The Migrants: \$ro Weekly in a Moresby Shanty Town. New Guinea and Australia, the Pacific and South-East Asia 2 (4): 60-66.

I970 Rural and Urban Villagers: A Bi-local Social System in Papua. PhD thesis, University of Hawai'i, Honolulu.

I993 Migration, Urbanization, and Rural-Urban Links: Toaripi in Port Moresby. In Contemporary Pacific Societies: Studies in Development 
and Change, edited by Victoria S Lockwood, Thomas G Harding, and Ben J Wallace, 219-232. Englewood Cliffs, NJ: Prentice Hall.

Salisbury, Richard, and Mary Salisbury

I972 The Rural Oriented Strategy of Urban Adaptation: Siane Migrants in Port Moresby. In The Anthropology of Urban Environments, edited by Thomas Weaver and Douglas White, 59-68. Society for Applied Anthropology Monograph Series, Ir. Washington, DC: Society for Applied Anthropology.

Scheper-Hughes, Nancy

1992 Death without Weeping: The Violence of Everyday Life in Brazil. Berkeley: University of California Press.

Stuart, Ian

1970 Port Moresby: Yesterday and Today. Sydney: Pacific Publications.

Turner, Mark

I990 Papua New Guinea: The Challenge of Independence. Melbourne: Penguin.

Turner, Victor

I972 The Forest of Symbols: Aspects of Ndembu Ritual. Ithaca: Cornell University Press.

Utulurea, G

I98I Gangs in Port Moresby. Point: Youth and Development I:I09-I I7.

Vele, Morea

1978 Rural Village and Peri-urban Settlement: A Case-study of Circulation from the Central Province. Occasional Paper 2. Port Moresby: Institute of Applied Social and Economic Research.

Waiko, John

I993 A Short History of Papua New Guinea. Melbourne: Oxford University Press.

Ward, Marion

I970 Urbanisation: Threat or Promise? New Guinea and Australia, the Pacific and South-East Asia 5 (I): 57-62.

White, Osmar

I972 Parliament of a Thousand Tribes. Second edition. Melbourne: Wren Publishing.

Willis, Ian

I974 Lae: Village and City. Melbourne: Melbourne University Press.

Wolfers, Edward P

I975 Race Relations and Colonial Rule in Papua New Guinea. Sydney: Australian and New Zealand Book Company.

Wrondimi, George

I994 Squatter Evictions and Government Policies on Settlement Communities in Papua New Guinea. Paper presented at World Conference of Social Workers, Colombo, Sri Lanka, July. 
Yeung, Yue-man, and Francois Belisle

I986 Third World Urban Development: Agency Responses with Particular Reference to IDRC. In Urbanisation in the Developing World, edited by David Drakakis-Smith, 99-I20. New Hampshire: Croom Helm. Young, F D

I976 Pasin bilong Raskal: Juvenile Crime in Port Moresby. Port Moresby Research Report 209. Port Moresby: Psychological Services Branch, Public Services Commission.

\section{Abstract}

As Papua New Guinea's well-publicized “law and order" problem continues unabated, calls are often made for the destruction of squatter settlements and the dispersal of their inhabitants as a solution to urban crime. This article examines the popular imagery of urban "squatter settlements" in Papua New Guinea, which represents them as criminogenic habitats of unemployed and impoverished migrants. The imagery is generally as misleading as that of squatter and shanty environments elsewhere in the third world-a topic that is familiar in critical academic literature. But it is argued here that the shared imagery cannot be submitted to an analysis that simply draws on political-economic generalizations about housing and marginalization in "developing" nations. The notion of squatter settlements in the independent nation of Papua New Guinea has a specific origin in the imagination and attitudes of Europeans in the preceding colonial period. The historical transformations through which the imagery has been perpetuated are examined to understand how present-day urban Papua New Guineans can continue to demonize settlements in the face of lived experience that contradicts this censorious discourse.

KEYWORDS: crime, housing, poverty, squatter settlements, urbanization. 